\title{
Fusarium basal rot: profile of an increasingly important disease in Allium spp.
}

\author{
Dung Le ${ }^{1,2}\left[\right.$ Kris Audenaert $^{1} \cdot$ Geert Haesaert ${ }^{1}$
}

Received: 18 September 2020 / Accepted: 16 February 2021 / Published online: 19 March 2021

(C) The Author(s) 2021

\begin{abstract}
Fusarium basal rot (FBR) is a soil-borne disease that affects Allium species worldwide. Although FBR has long been recognized as a major constraint to the production of economically important Allium species, information that could support disease management remains scattered. In this review, the current knowledge on the causal agents, symptomology and epidemiology, impact, and management strategies of FBR is synthesized. We highlight that FPR is associated with different complexes of several Fusarium species, of which Fusarium oxysporum and F. proliferatum are the most prevalent. These pathogenic complexes vary in composition and virulence, depending on sites and hosts, which can be challenging for disease management. Research to improve disease management using chemical pesticides, resistance cultivars, biocontrol agents, and cultural practices has achieved both promising results and limitations. Finally, research needs and future directions are proposed for the development of effective FBR management strategies.
\end{abstract}

Keywords Fusarium oxysporum $\cdot$ Fusarium proliferatum $\cdot$ Diversity $\cdot$ Phenology $\cdot$ Specialization of pathogens $\cdot$ Virulence variability

\section{Introduction}

Allium is a genus of monocotyledonous flowering plants that includes more than 600 species, of which onion (Allium cepa L.), leek (A. ampeloprasum var. porrum L.), shallot (A. cepa var. ascalonicum L., A. cepa var. aggregatum L.), garlic (A. sativum L.), and chive (A. schoenoprasum L.) are the most studied edible species (Maude 1998).

Although the majority of the common Allium species are originally native to Asia, they are now widely cultivated in different countries and climates, ranging from sub-tropical to temperate climates (Marrelli et al. 2018). In 2019, the global onion planted area is estimated to 5.192 .651 ha, which

Kris Audenaert and Geert Haesaert are both corresponding authors.

Dung Le

dungl@dlu.edu.vn

1 Faculty of Bioscience Engineering, Department of Plants and Crops, Ghent University, Valentin Vaerwyckweg 1, BE-9000 Ghent, Belgium

2 Faculty of Agriculture and Forestry, Dalat University, Dalat, Vietnam represents a production of 99.968.016 t (FAO 2020). China, India, the USA, and Egypt are the main producing countries, with quantities mounting to $24,966,366,22,819,000$, $3,170,270$, and 3,081,047 t for onions, respectively. The volume for garlic produced globally is $30,708,243$ t substantial, whereas the production of fresh Allium (onions, shallots) and leeks (including other alliaceous vegetables) only reached 4,491,246 $\mathrm{t}$ and 2,192,467 t, respectively (FAO 2020). Allium species are used not only for culinary preparations (Swamy and Veere Gowda 2006) but are also popular for medicinal purposes because most of them are rich in many bioactive compounds such as vitamins, carotenes, minerals, antioxidants, and antibiotic metabolites (Havey 1993; Sharifi-Rad et al. 2016).

Allium species can be grown from dried sets, bulblets (cloves), or seeds (Kamenetsky and Rabinowitch 2017). Long-term vegetative propagation occurs commonly in Allium crops, promoting the selection and adaptation of pathogens to Allium cultivars of diverse climatic and geographic regions (Katis et al. 2012). Despite their broad geographical distribution, Allium species are generally very sensitive to climate and soil. Allium species that produce bulbs such as onions and garlic generally require high temperature and bountiful sunshine, especially in the period from bulb growth to harvest. They also grow well in a loamy soil with well irrigation and 
excellent drainage (Kamenetsky and Rabinowitch 2017; Choudhary 2018). Poorly drained soil not only affects flavor and bulb development but also leads to the growth of diseases, especially soil-borne diseases.

Allium species are susceptible to a variety of fungal pathogens such as Fusarium spp., Colletotrichum spp., Alternaria spp., Peronospora spp., Botrytis spp., and Phoma spp., among others (Sharifi-Rad et al. 2016). Especially, Fusarium basal rot (FBR) is a major limitation to Allium production worldwide. FBR is also known as Fusarium rot or Fusarium wilt or basal plate rot of Allium spp. (Bayraktar et al. 2010; Stankovic et al. 2007). It is sometimes referred to "damping-off" or "dieback" disease of the seedlings (Kintega et al. 2020).

Despite the widespread occurrence of FBR in Allium spp., information on the disease is fragmented. The current work delves into the disease in terms of causal agents, impacts, symptomatology and epidemiology, population variability, and management strategies, highlighting knowledge gaps and research perspectives.

\section{Causal agents of FBR}

Globally, FBR of Allium spp. has been reported in Asia, Europe, the Americas, and Africa (Dauda et al. 2018; Dugan et al. 2003; Fletcher et al. 2017; Gálvez 2017; Gunaratna et al. 2019; Koike et al. 2003; Quesada-Ocampo et al. 2014; Ravi et al. 2014; Le et al. 2020). The disease has been associated with different species of Fusarium, including F. oxysporum, $F$. proliferatum, $F$. solani, $F$. acuminatum, $F$. redolens, $F$. verticillioides, $F$. equiseti, $F$. culmorum, $F$. falciforme and $F$. brachygibbosum, of which $F$. oxysporum and $F$. proliferatum are the most prevalent (Table 1).

Although FBR could also be caused by single Fusarium species (Dugan et al. 2003; Stankovic et al. 2007; TiradoRamírez et al. 2018a), a complex of different Fusarium species has been frequently found to be responsible for basal rot in Allium (Delgado-Ortiz et al. 2016; Ghanbarzadeh et al. 2014), which complicates identification and disease management. In addition, a correct estimation of the importance of each species in the disease complex is not easy. Even more compounding, the composition of the FBR pathogenic complex appears to vary with geographic regions and plant hosts and is also dynamic within and between growing seasons. For example, a complex of $F$. oxysporum, $F$. proliferatum, and $F$. redolens was responsible for basal rot of onion in Finland (Haapalainen et al. 2016), while $F$. oxysporum, F proliferatum, $F$. verticillioides, $F$. solani, and $F$. acuminatum were co-associated with basal rot of garlic in North Central Mexico (USA) (Delgado-Ortiz et al. 2016). Similarly, while most of the aforementioned species were found in onions, $F$. acuminatum and $F$. verticillioides were found only in garlic, and F. culmorum was found only in leek plants with similar symptoms (Table 1).

\section{Impact}

FBR results in yield and quality losses in Allium spp. both preand post-harvest in many parts of the world (Coşkuntuna and Özer 2008; Taylor et al. 2013). Disease incidence varies greatly (Köycü and Özer 1997), depending on the pathogenicity of Fusarium species, disease intensity, the susceptibility of varieties, and the plant's phenological stages (Cramer 2000).

Exact data on the impact of FBR on yield are scarce; however, $45 \%$ loss in yield and about $12-30 \%$ of bulb loss in storage have been reported in shallot (Sintayehu et al. 2011). Although onion can get infected by Fusarium spp. at any point in its developmental stage, losses due to FBR vary among growth stages and between regions (Cramer 2000). Among damping-off pathogens, Fusarium spp. can contribute to up to $70 \%$ of damage in nurseries (Mishra et al. 2014). Fusarium spp. also affect bulbs, causing losses up to $50 \%$ in the field and from 30 to $40 \%$ in storage, as was, for example, reported in Asia by Gupta and Gupta (2013) and Mishra et al. (2014). FBR was observed to affect $50 \%$ of seedlings in African fields (Dauda et al. 2018), whereas in southern New Mexico (USA), the disease incidence for fall-planted cultivars and spring-planted cultivars reached $40 \%$ and $29 \%$, respectively (Cramer 2000). Even when cultivated in virgin soil, the presence of FBR is quite high as observed in Zambia, where 80-90\% of the transplants were infected by $F$. oxysporum $\mathrm{f}$. sp. cepa, resulting in enormous losses in post-transplanting seedlings (44\%) and potential yield (69\%) (Naik and Burden 1981). The level of losses is usually higher in organic farms than in conventional farms (Haapalainen et al. 2016).

The production of other Allium species is also influenced by FBR. In garlic, FBR has been associated with $60 \%$ loss of both bulbs and seed crops (Cramer 2000; Sankar and Babu 2011), and about $10-60 \%$ of clove losses in storage (Cramer 2000; Quesada-Ocampo et al. 2014). Similarly, the transplanting of infected seedlings resulted in an increase of more than $50 \%$ of the disease in greenhouse leek in coastal California, causing significant economic losses (Koike et al. 2003). FBR has also been reported to impact the conservation of Allium germplasms, with the destruction of $20 \%$ of bulbs of A. giganteum (an ornamental Allium species) at a germplasm resource center in Yunnan Province, China, in 2013 (Zhang et al. 2016). Previously, F. oxysporum f. sp. cepae and $F$. proliferatum were responsible for severe losses of seed and clonal garlic collections of the National Plant Germplasm System in Pullman, WA, in 2002-2003 and 2005-2006 (Dugan et al. 2007). As FBR infection is favored by high temperature, the losses were projected to increase in the future due to climate change (Cramer 2000). 
Table 1 Fusarium spp. associating with basal rot disease of Allium spp

\begin{tabular}{|c|c|c|c|c|}
\hline Species & Hosts & Symptoms & Countries & References \\
\hline \multirow[t]{14}{*}{ F. oxysporum } & \multirow[t]{9}{*}{ Onion } & Basal rot & USA & Abawi and Lorbeer 1971 \\
\hline & & $\begin{array}{l}\text { Seedling death } \\
\text { Basal rot }\end{array}$ & USA & Cramer 2000 \\
\hline & & Basal rot & Zambia & Naik and Burden 1981 \\
\hline & & Basal rot & Finland & Haapalainen et al. 2016 \\
\hline & & Damping-off & Serbia & Stankovic et al. 2007 \\
\hline & & Basal rot & Turkey & Bayraktar et al. 2010 \\
\hline & & $\begin{array}{l}\text { Damping-off } \\
\text { Basal rot }\end{array}$ & Iran & Ghanbarzadeh et al. 2014 \\
\hline & & Basal rot & India & Manimaran et al. 2011 \\
\hline & & $\begin{array}{l}\text { Basal rot, } \\
\text { Damping-off }\end{array}$ & Israel & Kalman et al. 2020 \\
\hline & Onion & $\begin{array}{l}\text { Damping-off } \\
\text { Basal rot }\end{array}$ & Vietnam & Le et al. 2020 \\
\hline & \multirow[t]{3}{*}{ Garlic } & Blossom-end rot & Mexico & Delgado-Ortiz et al. 2016 \\
\hline & & Clove rot & USA, China & Dugan et al. 2003 \\
\hline & & Damping-off & Serbia & Stankovic et al. 2007 \\
\hline & Shallot & Basal rot & Hungary & Sintayehu et al. 2011 \\
\hline F. oxysporum & $\begin{array}{l}\text { Welsh onion } \\
\text { Leek }\end{array}$ & $\begin{array}{l}\text { Basal rot } \\
\text { Damping off } \\
\text { Damping off }\end{array}$ & Vietnam & Le et al. 2020 \\
\hline \multirow[t]{17}{*}{ F. proliferatum } & \multirow[t]{11}{*}{ Onion } & Basal rot & USA & Dugan et al. 2003 \\
\hline & & $\begin{array}{l}\text { Basal rot } \\
\text { Damping-off }\end{array}$ & Vietnam & Le et al. 2020 \\
\hline & & Basal rot & Finland & Haapalainen et al. 2016 \\
\hline & & $\begin{array}{l}\text { Basal rot, } \\
\text { Damping-off }\end{array}$ & Israel & Kalman et al. 2020 \\
\hline & & Seedling rot & Serbia & Stankovic et al. 2007 \\
\hline & & $\begin{array}{l}\text { Damping-off } \\
\text { Basal rot }\end{array}$ & Iran & Ghanbarzadeh et al. 2014 \\
\hline & & Bulb rot (purple, reddish) & India & Ravi et al. 2014 \\
\hline & & Salmon blotch & Israel & Fletcher et al. 2017 \\
\hline & & Basal rot & Serbia & Klokocar-Smit et al. 2008 \\
\hline & & Salmon blotch & USA & du Toit et al. 2003 \\
\hline & & Chlorosis, dry leaf tips, bulb rot & Argentina & Salvalaggio and Ridao 2012 \\
\hline & \multirow[t]{6}{*}{ Garlic } & Chlorosis and dry leaf tips, bulb rot & Argentina & Salvalaggio and Ridao 2012 \\
\hline & & Bulb rot, $\tan$ to salmon-pink & USA & Quesada-Ocampo et al. 2014 \\
\hline & & Bulb rot & USA & Dugan et al. 2003 \\
\hline & & Bulb rot, tan lesion & India & Sankar and Babu 2011. \\
\hline & & Blossom-end rot & Mexico & Delgado-Ortiz et al. 2016 \\
\hline & & Seedling rot & Serbia & Stankovic et al. 2007 \\
\hline \multirow[t]{4}{*}{$F$. proliferatum } & Garlic & - & Germany & Seefelder et al. 2002 \\
\hline & \multirow[t]{3}{*}{ Garlic } & Bulb rot & Hungary & Simey 1990 \\
\hline & & Bulb rot & Spain & Gálvez et al. 2017 \\
\hline & & Basal, clove rot & Italia & Tonti et al. 2017 \\
\hline \multirow[t]{4}{*}{ F solani } & \multirow[t]{3}{*}{ Onion } & $\begin{array}{l}\text { Damping off } \\
\text { Basal rot }\end{array}$ & $\begin{array}{l}\text { Serbia } \\
\text { Sri Lanka }\end{array}$ & $\begin{array}{l}\text { Klokocar-Smit et al. } 2008 \\
\text { Gunaratna et al. } 2019\end{array}$ \\
\hline & & & Iran & Ghanbarzadeh et al. 2014 \\
\hline & & Damping off & Vietnam & Le et al. 2020 \\
\hline & Garlic & Blossom-end rot & Mexico & Delgado-Ortiz et al. 2016 \\
\hline
\end{tabular}


Table 1 (continued)

\begin{tabular}{lllll}
\hline Species & Hosts & Symptoms & Countries & References \\
\hline & Welsh onion & $\begin{array}{l}\text { Basal rot } \\
\text { Damping off }\end{array}$ & Vietnam & Le et al. 2020 \\
F. acuminatum & Garlic & Blossom-end rot & Mexico & Delgado-Ortiz et al. 2016 \\
F. equiseti & Onion & Die-back & Nigeria & Dauda et al. 2018 \\
F culmorum & Leeks & Basal rot & Spain & Armengol et al. 2001 \\
& & & California & Koike et al. 2003 \\
F. falciforme & Onion & Basal rot & Mexico & Tirado-Ramírez et al. 2018b \\
F. brachygibbosum & Onion & Bulb rot & Mexico & Tirado-Ramírez et al. 2018a \\
F. redolens & Onion & Bulb rot & Finland & Haapalainen et al. 2016 \\
& & Damping off & Iran & Ghanbarzadeh et al. 2014 \\
F. verticillioides & Garlic & Basal rot & Mexico & Delgado-Ortiz et al. 2016 \\
F. acutatum & Blossom-end rot & Basal rot, & Israel & Kalman et al. 2020 \\
F. anthophilium & Onion & Damping-off & Israel & Kalman et al. 2020 \\
& & Basal rot, & & \\
\hline
\end{tabular}

\section{Symptomatology and epidemiology}

Primary inoculum causing FBR in Allium spp. often originates from soil and seeds (Ozer et al. 2004). Under favorable conditions, this inoculum can infect and colonize the host, resulting in disease symptoms. Infection and disease development are favored by moisture and high soil temperatures, with an optimum temperature of $28-32{ }^{\circ} \mathrm{C}$ (Abawi and Lorbeer 1972). Generally, FBR diseases can occur at all stages of Allium development (Taylor et al. 2019), but seedlings and dormant- or postharvest bulbs are the most susceptible (Cramer 2000).

Primary infection of Fusarium spp. occurs when the fungus penetrates directly into roots or through wounds on roots or on the basal parts of bulb scales (Bayraktar et al. 2010; Cramer 2000; Gutierrez et al. 2006). In early stages of germination, the infection results in a delay of seedling emergence (Gutierrez and Cramer 2005; Gutierrez et al. 2006) or damping-off of the seedlings (Fig. 1f) (Galeano et al. 2014; Kintega et al. 2020; Saxena and Cramer 2009). Fusarium pathogens also cause a loss of transplanted seedlings (Fig. 1a). Some infected seedlings can still survive but are poorly developed and stunted in growth. Occasionally, the pathogens infect plants in the seedling stage, but symptoms become more conspicuous during crop maturity or after harvest (Kintega et al. 2020). This was observed with several specific isolates of Fusarium spp., which were inoculated at the seedling stage (Kintega et al. 2020).

The first signs of mature plants being infected are the yellowing of leaves, followed by symptoms of withered and curly leaf. Subsequently these symptoms begin to spread downwards (Fig. 1b). Rotting of bulbs and the appearance of root abscission layer are noticeable symptoms of infection, leading to easily uprooting bulbs from roots (Fig. 1c). When the disease symptoms become severe, rotting of the entire bulb plates could occur and the development of white mycelium on the surface of bulbs or the basal areas of exterior bulb scales could be observed easily (Fig. 1d and e) (Cramer 2000; Lee et al. 2012). When infection occurs late in the season, symptoms may not be apparent at harvest but become advanced during storage (Cramer 2000; Retig et al. 1970).

Similar symptoms were observed on leek and other Allium spp. where affected roots appeared gray to pink, water soaked, or rotted. Infected roots and basal plates also form abscission layers separated easily from the rests of plant when uprooting. Seedlings, transplants, and mature plants could be all infected by the pathogen, causing a poor growth, chlorosis of old leaves, and collapse of plants (Fig. 1a) (Armengol et al. 2001; Koike et al. 2003).

FBR is a soil-borne disease (Cramer 2000; Köycü and özer 1997). The causal agents can survive either as chlamydospores in soil or as saprophytes in crop residues. Chlamydospores are particularly important, as they persist under adverse conditions with the absence of hosts for many years (Köycü and Özer 1997; Cramer 2000). Thus, the movement of infested soils plays a critical role in short distance spread of FBR. Fusarium spp. in Allium can produce micro- and macro-conidia, but their contribution to the transmission of FBR still remains unknown. The pathogen is also transmitted by latently infected planting materials (bulbs, transplants). A seed-borne mechanism has been revealed in certain cases such as $F$. oxysporum $\mathrm{f}$. sp. cepae in onion (Köycü and Özer 1997), and F. culmorum in leek (Koike et al. 2003). Weeds can contribute to the survival, proliferation, and spread of this pathogen (Abawi and Lorbeer 1972; 


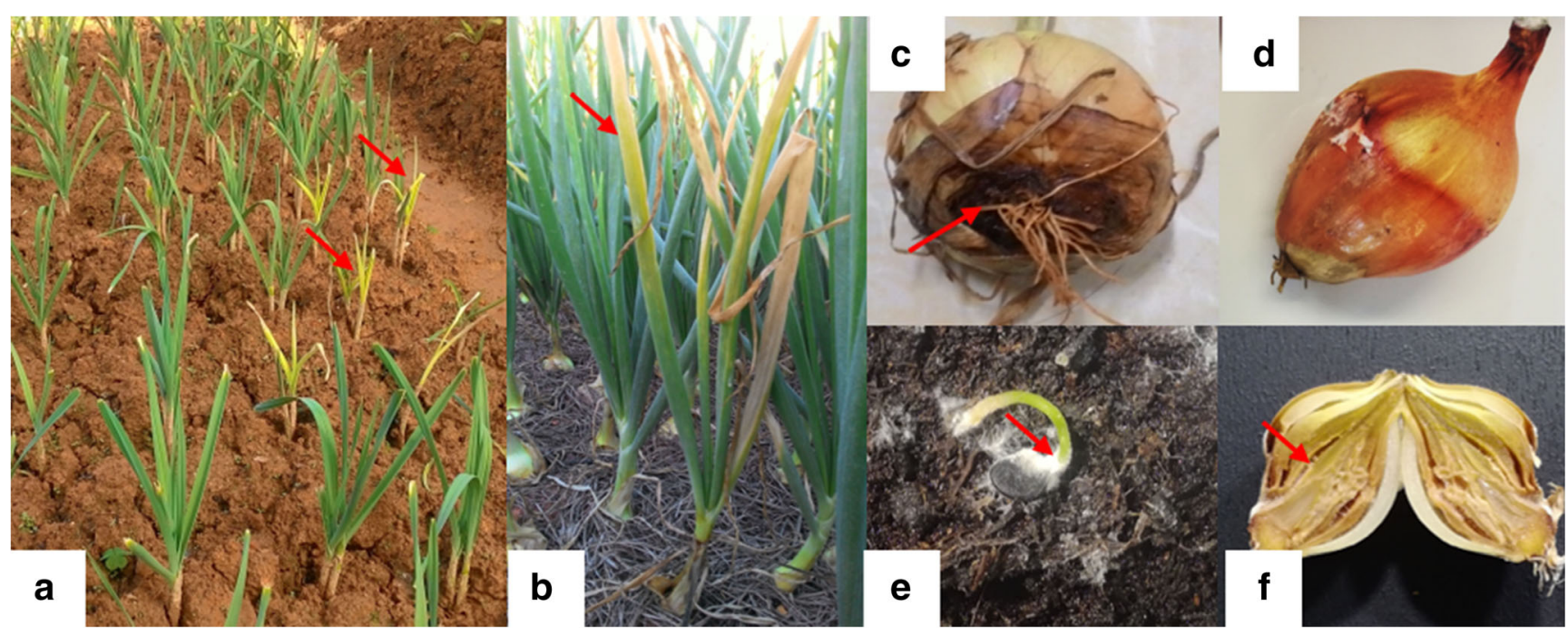

Fig. 1 Typical symptoms (red arrows) of Fusarium basal rot of Allium spp.: in transplanted leeks (a), in mature onion plants (b), in harvested bulb (c), in stored bulb (d), infected germinating seed (e), and inside of infected bulb (f)

Haapalainen et al. 2016). The widespread distribution of FBR can thus be attributed to their diverse spread mechanisms, in which spread through planting materials and latently infected bulbs are important factor in long distance dispersal of the pathogens. Haapalainen et al. (2016) have suggested that the increase of onion-pathogenic Fusarium species in Finland may be related to the import of planting materials.

So far, there is no evidence of secondary infection or spread of this disease in the field and even during storage. It appears therefore that Fusarium inoculum from soil or planting materials is critical for FBR occurrence in the field, while latently infected bulbs mainly contribute to postharvest basal rot of Allium spp. Therefore, a good FBR management strategy should focus on dealing with these inoculum sources. The development of FBR can thus be simulated as a monocycle disease (Fig. 2).

Furthermore, FBR creates favorable conditions for secondary pathogens to infect the bulb scales (Cramer 2000). Bacterial and Phoma bulb rots often occur in this fashion as secondary infections, although they are also known to be primarily problems on Allium. FBR can also associated with the feeding activity of insects like maggots, which are attracted by rotten tissues. However, the interaction between FBR and secondary parasites is not well understood. The occurrence of secondary pathogens can contribute to accelerate bulb decay, but assessing the contribution of each pathogen to the process is very challenging (Cramer 2000). Moreover, these mixed infections would present a difficulty in disease management, as diagnosis becomes a challenge.

\section{Pathogenic variability and host susceptibility}

Disease outcome is the result of a host-pathogen interaction under the influence of environmental conditions. The diversity of Fusarium and Allium species and the occurrence of mixed infections allow for a multiplicity of FBR disease outcomes (Dissanayake et al. 2009; Gei et al. 2014; Ozer et al. 2004).

The virulence of Fusarium spp. varies between Allium species (Galván et al. 2008). In general, F. oxysporum f. sp. cepae is more common and pathogenic in onions than other species, while $F$. proliferatum tends to be more virulent to other Allium species such as garlic and shallot (Palmero et al. 2012). However, in Finland, F. proliferatum was found in onions to be more dominant and aggressive than $F$. oxysporum f. sp. cepae (Haapalainen et al. 2016). In a similar report from Serbia, $F$. proliferatum isolates from garlic were even more pathogenic to onions than those from onions (Stankovic et al. 2007).

In situations of mixed infections by multiple Fusarium spp., one species may be more important than the others at particular stage of Allium phenology. Such is for instance the case in Vietnam, where co-infection by $F$. solani, $F$. proliferatum, and $F$. oxysporum was reported on onion, but while $F$. solani was only highly virulent on seedlings, $F$. proliferatum and $F$. oxysporum severely affected bulbs as well as seedlings (Le et al. 2020). Similarly, reports from Iran, Finland, and Burkina Faso suggest that $F$. solani and $F$. redolens typically results in lesions on seedlings while occurring in asymptomatic infections on bulbs (Ghanbarzadeh et al. 2014; Haapalainen et al. 2016; Kintega et al. 2020). Given that natural FBR epidemics are rarely found to be associated with a single species, identifying key species at a specific stage of host development can be useful in adjusting effective control strategies.

Seedling age and growth stage have been proposed as major determinants of FBR presence on Allium spp. (Cramer 2000; Galván et al. 2008; Galeano et al. 2014). FBR tends to be more aggressive when infection establishes at an early stage of seedling development and on mature bulbs in storage (dormant 


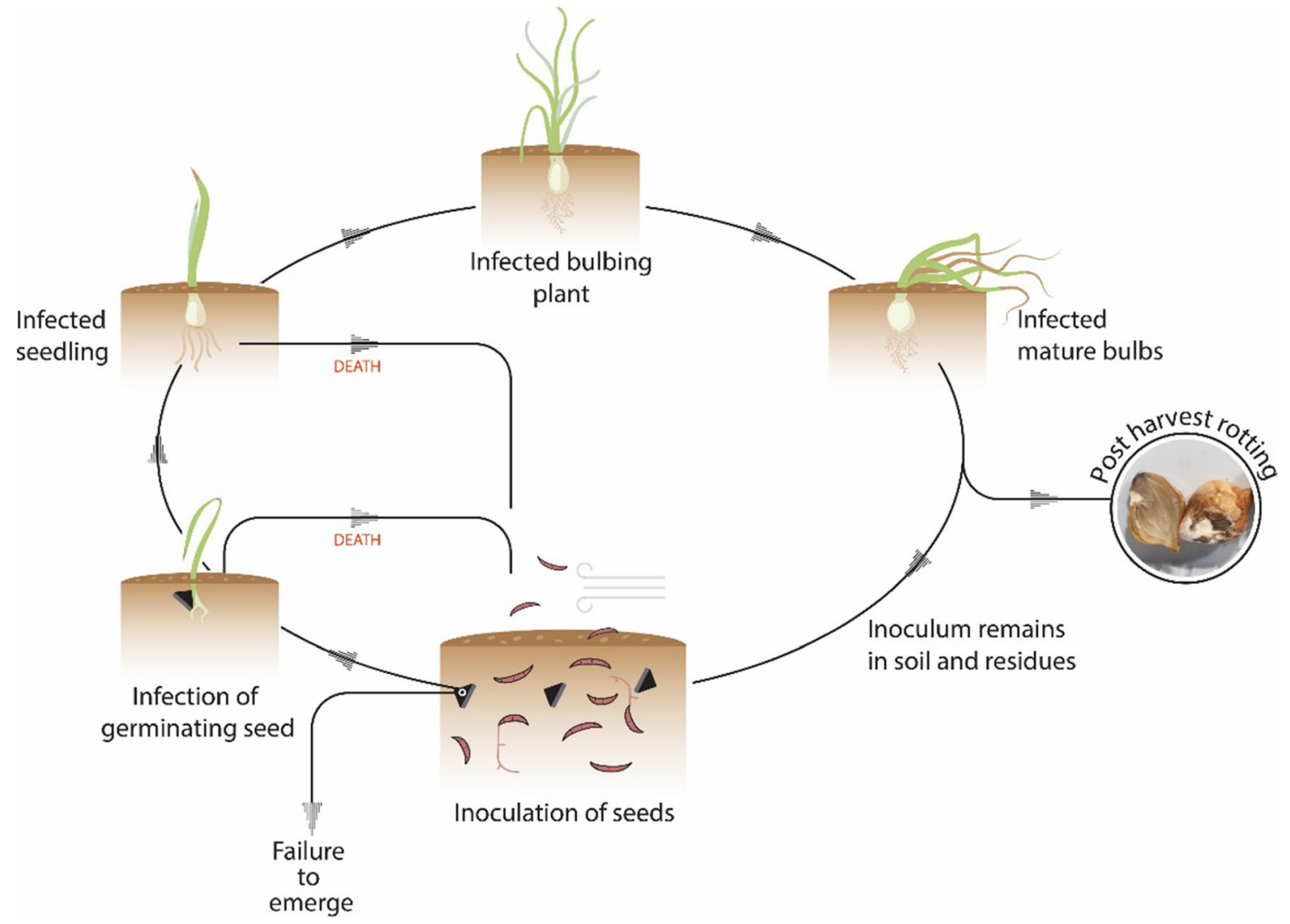

Fig. 2 Disease cycle of Fusarium basal rot in onion (Allium cepa L.). Notice that Fusarium spp. can infect at all developmental stages of onion. The figure does not include the infection of seedlings and mature plants

bulbs) (Retig et al. 1970; Stadnik and Dhingra 1997; Cramer 2000; Taylor et al. 2013; Galeano et al. 2014). Similarly, disease aggressiveness is also affected by the age of transplants, where older transplants might show no symptoms even though pathogenic fungi can still be recovered from them (Stadnik and Dhingra 1997). Age-related resistance is driven by diverse mechanisms in host plants (Develey-Riviere and Galiana 2007). Changes in the contents and biochemical activities of proteins, enzymes, and phenolics during developmental stages of host plants may determine the outcome of the interaction of plants with the pathogen. Galeano et al. (2014) have found that the enhanced activities of peroxidase and glucanase in onion seedlings after germination (at 7 days post-sowing) were significantly linked to the prompt decline in their susceptibility towards a Fusarium infection.

The susceptibility of a cultivar is a variable factor (Taylor et al. 2013). Indeed, the specialization of pathogens, which is influenced by host phenology, is likely to exist among Fusarium population, leading to some Fusarium isolates being only pathogenic in a certain set of Allium cultivars and even at specific growth stages of the host plants (Cramer 2000; Galván et al. 2008; Kintega et al. 2020). For example, some isolates of $F$. oxysporum f. sp. cepae, $F$. proliferatum, and $F$. solani cause severe disease symptoms on onion seedlings; however, others tend to be more virulent on mature bulbs (Kintega et al. 2020). This complex interaction may be related to changes in gene expression leading to biological changes, but the molecular mechanisms involved remains unknown. Furthermore, the aggressiveness of Fusarium isolates is also a variable (Taylor et al. 2013) that changes greatly among fields even within the same geographic region (Cramer 2000; Taylor et al. 2013; Gei et al. 2014). This could be a plausible explanation for inconsistent responses of tolerant cultivars under different conditions.

\section{Fusarium basal rot management}

\section{Chemical control}

Soil treatment or soil fumigation is among the most effective chemical control measures for FBR. Sodium salts like metam sodium and dazomet have shown their ability to effectively control FBR and improve plant growth (Nico and González Sánchez 2012). Sodium metabisulfite (at $0.4 \%$ ) completely inhibited mycelial growth of $F$. oxysporum f. sp. cepae (Turkkan and Erper 2014). Compared to chemical treatments of planting materials, soil fumigation is more effective because it effectively reduces pathogenic propagules and it is especially suited for the control of soil-borne diseases (Sumner et al. 1997). 
However, this measure involves mostly broad-spectrum fungicides that can kill beneficial microorganisms in soil.

Carbendazim, benomyl, and prochloraz are mostly used, alone or in combination with other fungicides to control FBR via a soil treatment (Abd-Elrazik et al. 1990; Naik and Burden 1981; Özer and Köycü 1998; Sintayehu et al. 2011). Seed treatments with benomyl and thiram resulted in a limited seed contamination of $F$. oxysporum, improved seedling emergence, and reduced damping-off, whereas seed coating with prochloraz provided remarkable protection in infested soil (Özer and Köycü 1998). Shallot basal rot can be managed effectively by bulb dressing or dip treatment in prochloraz or a mixture of carbendazim and imidacloprid (Sintayehu et al. 2011). Pre-planting dipping of onion bulbs with benomyl ( $100 \mu \mathrm{g} \cdot \mathrm{mL}^{-1}$ for $15 \mathrm{~min}$.) reduced basal rot by $65 \%$ and enhanced yield with $54 \%$ (Naik and Burden 1981). Similar results were obtained when combined with vinclozolin (Özer and Ömeroğlu 1995) or mancozeb (Naik and Burden 1981).

The efficacy of chemicals in controlling FBR in greenhouse or at small scale under controlled conditions is undeniable. However, their field efficacy greatly varies and even it does not provide sufficient control of the disease (Ozer et al. 2002). In Finland, the incidence of bulbs infected with Fusarium spp. is up to $20 \%$ despite the application of chemical treatments (Haapalainen et al. 2016). This is probably due to a great variation of Fusarium populations and environmental uncontrolled factors under field conditions. Hence, field validation should be done to address not only the short-term disease response but also the impacts on the microbiological community of soils and plants (rhizosphere) (Dita et al. 2018) including the recolonization of soil.

Furthermore, the repeated application of fungicides not only causes environmental and ecological problems but also enhances the development of fungicide resistance in pathogens (Dekker 1976; Mishra et al. 2014). Although there has been no confirmed resistance in the Fusarium population in Allium, the occurrence of resistance to most fungicides such as benomyl, carbendazole, prochloraz, thiophanate-methyl, thiabendazole, and fludioxonil has been reported in the Fusarium populations pathogenic to lily, tomato, potato, wheat, chili, and sugarcane (Chen et al. 2007; Chen and Zhou 2009b; Chen and Zhou 2009a; Chung et al. 2009; Lugosch et al. 2011; Petkar et al. 2017; Xu et al. 2019). For instance, within $F$. sulphureum population, more than $90 \%$ of isolates from the seed potatoes from a storage in New Bundeslaender (Germany) were resistant to carbendazim, and data from isolates coming from ware potatoes indicated $60-74 \%$ resistance (Stachewicz et al. 1992). Increasing concerns in the development of fungicide resistance in Fusarium species in Allium are validated by recent findings that have shown a decrease in the effectiveness of carbendazole in controlling FBR on the field (El-Mougy and Abdel-Kader 2019).

\section{Crop rotation}

Inoculum build-up in soil is a key feature of soil-borne pathogens, and crop rotation is expected to be an effective solution. Successive cultivation of susceptible Allium species and varieties in fields with an infection history leads to uncontrolled damage (Abawi and Lorbeer 1972). Furthermore, the susceptibility of Allium species such as onions, garlics, leeks, chives, and scallions to $F$. proliferatum and $F$. oxysporum $\mathrm{f}$. sp. cepae isolates coming from garlic and onion has been observed (Palmero et al. 2012), suggesting a rotation with crops from other families. A minimum of 4 years of rotation with such crops is recommended to reduce soil infection and bulbs losses (Cramer 2000; Wright et al. 2015). In the past, a sequence of crops has been found to be included in a rotation system for the purpose of reducing the pathogen inoculum and limiting onion FBR (Leoni et al. 2013).

However, crop rotation is likely not totally effective because pathogen can survive for a long time either in the soil or in/on the roots of symptomless alternative hosts (Abawi and Lorbeer 1972). Recently, some isolates of $F$. oxysporum f. sp. asparagus, $F$. proliferatum, and $F$. solani isolated from asparagus have also shown their capability to attack onion and garlic (Molinero-Ruiz et al. 2011), and even crops from completely distant families such as maize, wheat, potato, and sunflower are also suggested as reservoirs of these pathogens (Molinero-Ruiz et al. 2011). This shows the complexity of the Fusarium population related to diseases in Allium species. In fact, it is not clear whether Fusarium inoculum accumulates from previous crops in the crop rotation system or whether this might lead to an increased diversity of Fusarium pathogens on Allium species. If so, there would be a relation between crop species susceptible to Fusarium species in the historical crop rotation system of a field and the diversity of the Fusarium population in onion; e.g., the more susceptible crops rotated the greater the population diversity. This would probably be a plausible explanation for differences in the Fusarium complex that were found among onion production regions around the world. Thus, in the complex of Fusarium species associated to basal rot disease in onions, it is likely that only one or two species are actually responsible for the disease, and the others are likely to exist only on the onion as its intermediate or alternative host.

\section{Resistant cultivars}

The use of resistant cultivars to control FBR has become highly significant due to undesirable impacts from fungicides (Cramer 2000; Galván et al. 2008; Lacy and Roberts 1982). Several Allium species such as A. fistulosum, A. schoenoprasum, and A. galanthum have been found to be consistently resistant to FBR (Abawi and Lorbeer 1971; Galván et al. 2008), but they are not popular cultivated species. Also, A. pskemense, A. roylei, and $A$. galanthum exhibited intermediate resistance to FBR 
(Galván et al. 2008). Gene resources of such species were exploited for the development of resistance in onion against Fusarium spp. (Galván et al. 2008; Palmero et al. 2012; Taylor et al. 2013) because of no complete resistance found in onion selections (Retig et al. 1970; Lacy and Roberts 1982; Cramer 2000; Lopez and Cramer 2004; Gutierrez and Cramer 2005; Galván et al. 2008; Taylor et al. 2013). Among short-day onion cultivars, "NuMex Luna" and "NMSU 00-32" had the highest resistance potential at the seedling stage, whereas "NMSU 00-13-1" showed the best resistance level in the mature stage (Lopez and Cramer 2004). "NMSU 99-32", "NuMex Aurthur" and "NuMex Jose Fernandez" were among wintersown onion cultivars found highly resistant to $F$. oxysporum $\mathrm{f}$. sp. cepae (Cramer 2000; Gutierrez et al. 2006). In a similar study, Galván et al. (2008) found that onion cultivar 'Rossa Savonese' was intermediately resistant to FBR. Recently, cvs "Ailsa Craig Prizewinner" and "White Lisbon" showed the highest levels of resistance to $F$. oxysporum f. sp. cepae from UK and Netherlands of all commercial onion cultivars in UK (Taylor et al. 2013).

Once the infection is established in the field, the use of resistant cultivars is essential and the most effective method to control the disease. Despite recent efforts in the development of FBR-resistant cultivars (Abawi and Lorbeer 1971; Cramer 2000; Galván et al. 2008; Gutierrez and Cramer 2005; Gutierrez et al. 2006; Lacy and Roberts 1982; Retig et al. 1970; Saxena and Cramer 2009), the research on and application of resistant cultivars under the field circumstances are still facing a major challenge due to the large variability in the virulence of the Fusarium spp. responsible for FBR. The response of Allium species to the infection varies depending on their development stages (Galeano et al. 2014), pathogen virulence and cultivar properties (Dissanayake et al. 2009; Gei et al. 2014). The resistance mechanism of the cultivar and disease profile are completely unknown (Gei et al. 2014). Regardless of whether or not the interactions exist between isolates and specific cultivars resulting in disease expression, it is likely that the response of a selection to the infection of Fusarium does not depend largely on the characteristics of the cultivars, but the virulence of Fusarium species or its isolates occurs under specific conditions. Recent studies have expressed an increasing skepticism about the effectiveness of resistant cultivars. In fact, resistance selection is usually done locally and thus effective against a local, particular set of Fusarium spp. (Gei et al. 2014). Resistant cultivars under one condition may appear to be susceptible under another condition (Galván et al. 2008; Saxena and Cramer 2009; Taylor et al. 2013) or under disease pressure from other isolates (Gei et al. 2014). This has been demonstrated in Argentina where resistant onion lines from overseas had been defeated by other pathogenic isolates of $F$. oxysporum $\mathrm{f}$. sp. cepae isolated in the country (Gei et al. 2014). These reviews seem to support the hypothesis that Fusarium-resistant varieties may be able to control a limit specific isolates within a certain range when the changes in the population of Fusarium spp. have not taken place yet. Therefore, the application of resistant cultivars for disease control under practical conditions seems to bring very limited effectiveness. Selection of FBRresistant cultivars is still ongoing, and our suggestion is that screenings in the future should be done with a larger set of Fusarium isolates from many regions and carried out over the growth stages of Allium hosts.

\section{Biological control}

\section{Biocontrol agents}

Trichoderma spp. are the most widely applied biocontrol agents against many pathogens (Asad et al. 2014; Bae et al. 2016; Kifle et al. 2017; Muthukumar et al. 2011; Sid Ahmed et al. 1999). Inhibition of $F$. oxysporum f. sp. cepae by Trichoderma viride has been already shown in vitro (Ilhe et al. 2013; Rajendran and Ranganathan 1996). Combined seed treatment of $T$. viride and Pseudomonas fluorescens reduced onion basal rot incidence both in pot and in field conditions (Rajendran and Ranganathan 1996). A similar trial was conducted in India where FBR could be managed significantly $(85 \%)$ by a mixture of $T$. harzianum (TH3) and Pseudomonas sp. (Pf12+ Pf27) isolated from the rhizospherical soil in naturally infected onion fields (Malathi 2015). T. harzianum KUEN 1585 (commercial product, Sim $囚$ Derma) has been shown to be effective in prevention and control of FBR in onion both in vitro and in pot experiments. This strain was particularly effective in stimulating the formation of antifungal compounds in onion and partly contributed to improve bulb size at harvest (Coşkuntuna and Özer 2008). Another strain of T. harzianum, T100 (at the rate of $1 \times$ $10^{6}$ cfu.g $^{-1}$ ), was shown to control FBR of onion caused by $F$. proliferatum in the presence of Glomus mosseae (3 $\mathrm{g}$ soil containing 80 chlamydospores. $\mathrm{mL}^{-1}$ ) — an arbuscular mycorrhizae (AM) being capable of effectively stimulating onion growth, although the presence of Trichoderma resulted in a partial inhibition of AM root colonization in onion (Ghanbarzadeh et al. 2016). T. asperellum and T. virens inhibit $F$. solani growth, a causal agent of damping off of onion seedlings in Sri Lanka (Gunaratna et al. 2019).

In addition, members of the genus Bacillus are well-known antibiotic producers exploited for biocontrol of FBR. Bacillus subtilis has exhibited its potential in controlling the disease both in vitro and in pot experiments (Manimaran et al. 2011).

From another perspective, several biocontrol agents might make certain contributions to improve onion growth through activating host key metabolite pathways. $T$. longibrachiatum isolated from desert soil triggers key metabolites resulting in the improvement of onion growth and its resistance to F. oxysporum f. sp. cepae (Abdelrahman et al. 2016). Furthermore, the volatile compounds produced by Bacillus 
species provided antifungal activity to inhibit mycelial growth of $F$. oxysporum which causes wilt of onion (Sharifi Tehrani and Ramezani 2003).

In general, the research and application of biological agents to control FBR is still limited: mainly studies focused on Trichoderma spp. tested in vitro and in pot experiments; their effectiveness is highly variable in relation to experimental conditions, making it difficult to successfully apply in the field.

\section{Plant extracts}

Extracts or essential oils from some plant species such as Brassica crops, Fabaceae crops, neem trees, and allelopathic grasses have antifungal potential against soil-borne diseases (Bowers and Locke 2000; Javaid and Rauf 2015; Moutassem et al. 2019). In an in vitro test, extracts of Ethiopian mustard (Brassica carinata) and rape seed (B. napus) showed high inhibition on the growth of shallot $F$. oxysporum $\mathrm{f}$. sp. cepae pathogen (Sintayehu et al. 2014). Previously, extracts from allelopathic grasses (Cenchrus pennisetiformis, Imperata cylindrica, and Dichanthium annulatum) were also effective in vitro to control $F$. solani (Shafique et al. 2004). Among the oil cake extracts of neem, mahua, groundnut, mustard, pungam, castor, and gingelly investigated, neem and mustard extract exhibited an effective inhibition of the growth of $F$ oxysporum f. sp. cepae in India (Saravanakumari et al. 2019; Yadav et al. 2014). Some botanical extracts and oils also partially stimulate plant defense mechanisms to some extent as suggested by Moutassem et al. (2019).

\section{Soil amendments based on natural organic matters}

Biodegradable materials such as crop residues, fresh plant extracts, and dry botanical biomass can be used as biofumigants, or a supplemental resource of microbial antagonists (Hoitink and Boehm 1999), to improve soil properties for biological agents (Ozer et al. 2002) as well as stimulating resistance in plants (Bonanomi et al. 2007; Yogev et al. 2010; Zhang et al. 1996).

The incidence of onion bulb rot was reduced in soil amended with stalks of sunflower (Helianthus annuus L.), alfalfa (Medicago sativa L.), or Hungarian vetch (Vicia pannonica Crantz) (Ozer et al. 2002). Sintayehu et al. (2014) found that rapeseed crops (B. napus) and Ethiopian mustard (B. carinata) have highly potential to reduce incidence and severity of FBR with $20-30 \%$ in shallot crops. Likewise, dry biomass of pigweed (Chenopodium album), swinecress (Coronopus didymus), and chinaberry (Melia azedarach) have shown a significant potential for controlling FBR on onion (Javaid and Rauf 2015). In general, the enrichment of organic matter with biocontrol agents to produce the so-called organic fertilizers obtained promising results in disease management.
Dry leaf biomass of solanaceous weed (Withania somnifera) mixed with $T$. harzianum to control FBR in onion in Pakistan (Akhtar and Javaid 2018).

The use of organic amendments with municipality food waste compost to control FBR of onion was evaluated in combination with soil solarization. However, the efficacy of soil solarization reduced significantly from 68.7 to $16.3 \%$ (2010) and from 76.9 to $4.6 \%$ (2011) when soil was solarized after applying the organic amendments (Carrieri et al. 2013), indicating an adverse impact of organic amendments on the results of solarization.

To summarize, although many studies have shown a great potential of compost amendments and organic matter, the effectiveness of this technique on field level is inconsistent and unpredictable (Bonanomi et al. 2007; Carrieri et al. 2013). It may sometimes even be counterproductive and hamper the control of pathogens (Carrieri et al. 2013; Hoitink and Boehm 1999).

\section{Other measures}

A number of other measures have also been studied and applied effectively, making important contributions to the management strategies of Fusarium diseases in Allium spp. Bulb submerging in hot water (at $45-50^{\circ} \mathrm{C}$ ) for 30 min was effective in controlling FBR of shallot without negative effects on seed sprouting and seedling growth (Wibowo et al. 2016). Initially, hot water treatment and fungicides effectively controlled basal rot of narcissi ( $F$. oxysporum f. sp. narcissi) in the field and during the storage (Hanks 1996). Soil solarization has been used to decrease the inoculum level in soil resulting in a partial reduction of FBR (Satour et al. 1991). Also, heating the soil layers on a seedbed by burning plant residues such as straw and thresh can provide an effective control measure to FBR in seedling production (Awuah et al. 2009). Furthermore, the maintenance of field hygiene and a regular treatment of equipment and machinery are also important measures to prevent infection sources of FBR disease.

\section{Conclusions and perspectives}

Fusarium basal rot (FBR) caused by a complex set of Fusarium species is an important disease of Allium crops pre- as well as post-harvest. The complexity of this disease is caused by different Fusarium species with a divergence in virulence and host susceptibility. Despite the fact that many control measures have been undertaken, the disease remains a major problem for Allium producers worldwide. It emerged in this review that each measure has a certain limitation in controlling FBR. Integrated pest management (IPM) is probably the ultimate option to explore in the context of agricultural ecosystem management. For a soil-borne disease such as 
FBR, the management of soil and planting materials is an important dimension of this strategy. This review suggests the integrated use of environmentally friendly methods to proactively prevent infection and limit damage, with an emphasis on resistant cultivars and biological control using disease-free planting material and regularly maintaining field sanitation. Furthermore, the underlying aspects in Allium-Fusarium interaction need to be interpreted in order to provide the critical insights for the development of effective resistant varieties in the future. Finally, biological control is a promising method that needs to be explored more intensively before it can be implied in nurseries or in production fields.

Acknowledgements The research is part of a Ph.D. project about Fusarium basal rot in Allium spp. in Vietnam. The authors are thankful to the Ministry of Agriculture and Rural Development of Vietnam for financial support to the Ph.D. research project (2613/QD/BNN-TCCB). The authors are also grateful to the Department of Plants and Crops, Faculty of Bioscience Engineering, Ghent University, Belgium for supporting the facilities, equipment, materials, and techniques to implement the project. We also thank Boris Bekaert (LAMP, Ghent University) for the graphic design of Fusarium's life cycle.

Author contribution Kris Audenaert and Geert Haesaert conceived of the current idea. The initial draft was written by Dung Le. All authors provided critical comments and helped shape the final manuscript.

Data availability Data sharing is not applicable to this article as no datasets was generated or analyzed during the current study.

\section{Declarations}

Conflict of interest The authors declare no competing interests.

Open Access This article is licensed under a Creative Commons Attribution 4.0 International License, which permits use, sharing, adaptation, distribution and reproduction in any medium or format, as long as you give appropriate credit to the original author(s) and the source, provide a link to the Creative Commons licence, and indicate if changes were made. The images or other third party material in this article are included in the article's Creative Commons licence, unless indicated otherwise in a credit line to the material. If material is not included in the article's Creative Commons licence and your intended use is not permitted by statutory regulation or exceeds the permitted use, you will need to obtain permission directly from the copyright holder. To view a copy of this licence, visit http://creativecommons.org/licenses/by/4.0/.

\section{References}

Abawi GS, Lorbeer JW (1971) Pathological histology of four onion cultivars infected by Fusarium oxysporum f. sp. cepae. Phytopathology 61:1164-1169

Abawi GS, Lorbeer JW (1972) Several aspects of the ecology and pathology of Fusarium oxysporum f. sp. cepae. Phytopathology 62: 870-876

Abdelrahman M, Abdel-Motaal F, El-Sayed M, Jogaiah S, Shigyo M, Ito SI, Tran LSP (2016) Dissection of Trichoderma longibrachiatum- induced defense in onion (Allium cepa L.) against Fusarium oxysporum f. sp. cepa by target metabolite profiling. Plant Science 246:128-138

Abd-Elrazik AA, Fahmy FG, Amein AM, El-Amein AI (1990) Role of onion seeds in transmission of damping-off causal fungi and chemical control of the disease. Assiut Journal of Agricultural Sciences 21:173-193

Akhtar R, Javaid A (2018) Biological management of basal rot of onion by Trichoderma harzianum and Withania somnifera. Planta Daninha 36. Available at. https://doi.org/10.1590/s010083582018360100009. Accessed 20 April 2020

Armengol J, Vicent A, Sales R, García-Jiménez J, Rodríguez JM (2001) First report of basal rot of leek caused by Fusarium culmorum in Spain. Plant Disease 85:679-679

Asad SA, Ali N, Hameed A, Khan SA, Ahmad R, Bilal M, Shahzad M, Tabassum A (2014) Biocontrol efficacy of different isolates of Trichoderma against soil borne pathogen Rhizoctonia solani. Polish Journal of Microbiology 63:95-103

Awuah RT, Kwoseh C, Koranteng SL, Okpala ROC, Amoako-Attah I (2009) Appearance of Fusarium basal rot of onion in the Kwahu south district of Ghana. Ghana Journal of Horticulture 7:84-88

Bae SJ, Mohanta TK, Chung JY, Ryu M, Park G, Shim S, Hong SB, Seo H, Bae DW, Bae I, Kim JJ, Bae H (2016) Trichoderma metabolites as biological control agents against Phytophthora pathogens. Biological Control 92:128-138

Bayraktar H, Türkkan M, Dolar FS (2010) Characterization of Fusarium oxysporum f.sp. cepae from onion in Turkey based on vegetative compatibility and rDNA RFLP analysis. Journal of Phytopathology 158:691-697

Bonanomi G, Antignani V, Pane C, Scala F (2007) Suppression of soilborne fungal diseases with organic amendments. Journal of Plant Pathology 89:311-324

Bowers JH, Locke JC (2000) Effect of botanical extracts on the population density of Fusarium oxysporum in soil and control of Fusarium wilt in the greenhouse. Plant Disease 84:300-305

Carrieri R, Raimo F, Pentangelo A, Lahoz E (2013) Fusarium proliferatum and Fusarium tricinctum as causal agents of pink rot of onion bulbs and the effect of soil solarization combined with compost amendment in controlling their infections in field. Crop Protection 43:31-37

Chen Y, Zhou M-G (2009a) Sexual recombination of carbendazim resistance in Fusarium graminearum under field conditions. Pest Management Science 65:398-403

Chen Y, Zhou M (2009b) Characterization of Fusarium graminearum isolates resistant to both carbendazim and a new fungicide JS39919. Disease Control and Pest Management (APS) 99:441-446

Chen C, Wang J, Luo Q, Yuan S, Zhou M (2007) Characterization and fitness of carbendazim-resistant strains of Fusarium graminearum (wheat scab). Pest Management Science 63:1201-1207

Choudhary DR (2018) Scientific cultivation of onion (Allium cepa L.). In: Peter KV (ed) Phytochemistry of fruits and vegetables. Brillion Publishing, New Delhi, pp 239-260

Chung WH, Chung WC, Ting PF, Ru CC, Huang HC, Huang JW (2009) Nature of resistance to methyl benzimidazole carbamate fungicides in Fusarium oxysporum f.sp. lilii and $F$. oxysporum f.sp. gladioli in Taiwan. Journal of Phytopathology 157:742-747

Coşkuntuna A, Özer N (2008) Biological control of onion basal rot disease using Trichoderma harzianum and induction of antifungal compounds in onion set following seed treatment. Crop Protection $27: 330-336$

Cramer CS (2000) Breeding and genetics of Fusarium basal rot resistance in onion. Euphytica 115:159-166

Dauda W, Alao S, Zarafi A, Alabi O (2018) First report of die-back disease of onion (Allium cepa L.) induced by Fusarium equiseti (Mart) Sacc in Nigeria. International Journal of Plant \& Soil Science 21:1-8 
Dekker J (1976) Acquired resistance to fungicides. Annual Review of Phytopathology 14:405-428

Delgado-Ortiz JC, Ochoa-Fuentes YM, Cerna-Chávez E, Beltrán-Beache M, Rodríguez-Guerra R, Aguirre-Uribe LA, Vázquez-Martínez O (2016) Patogenicidad de especies de Fusarium asociadas a la pudrición basal del ajo en el centro norte de México. Revista Argentina de Microbiología 48:222-228

Develey-Riviere MP, Galiana E (2007) Resistance to pathogens and host developmental stage: a multifaceted relationship within the plant kingdom. New Phytologist 175:405-416

Dissanayake MLMC, Kashima R, Tanaka S, Ito S (2009) Pathogenic variation and molecular characterization of Fusarium species isolated from wilted welsh onion in Japan. Journal of General Plant Pathology 75:37-45

Dita M, Barquero M, Heck D, Mizubuti ESG, Staver CP (2018) Fusarium wilt of banana: current knowledge on epidemiology and research needs toward sustainable disease management. Front Plant Sciences 9:1468

du Toit L, Inglis DA, Q Pelter G (2003) Fusarium proliferatum pathogenic on onion bulbs in Washington. Plant Disease 87:750-750

Dugan FM, Hellier BC, Lupien SL (2003) First report of Fusarium proliferatum causing rot of garlic bulbs in North America. Plant Pathology 52:426-426

Dugan F, Hellier B, Lupien S (2007) Pathogenic fungi in garlic seed cloves from the United States and China, and efficacy of fungicides against pathogens in garlic germplasm in Washington State. Journal of Phytopathology 155:437-445

El-Mougy NS, Abdel-Kader MM (2019) Biocontrol measures against onion basal rot incidence under natural field conditions. Journal of Plant Pathology 101:579-586

FAO (2020). Available at: http://www.fao.org/faostat/en/\#data/QC. Accessed 30 Jan 2021

Fletcher J, Gamliel A, Stack JP, Dehne HW, Isack Y, Moncrief I (2017) Applications and assessment of microbial forensics in a field outbreak of salmon blotch of onion in Israel. Practical Tools for Plant and Food Biosecurity: Results from a European Network of Excellence: $257-287$

Galeano P, Gonzalez PH, Fraguas LF, Galvan GA (2014) Age-related resistance to Fusarium oxysporum f. sp. cepae and associated enzymatic changes in seedlings of Allium cepa and A. fistulosum. Tropical Plant Pathology 39:374-383

Galván GA, Koning-Boucoiran CFS, Koopman WJM, Burger-Meijer K, González PH, Waalwijk C, Kik C, Scholten OE (2008) Genetic variation among Fusarium isolates from onion, and resistance to Fusarium basal rot in related Allium species. European Journal of Plant Pathology 121:499-512

Gálvez L (2017) Fusarium proliferatum - causal agent of garlic bulb rot in Spain: genetic variability and mycotoxin production. Food Microbiology 67:41-48

Gei PFC, Valdez JG, Piccolo RG, Galmarini CR (2014) Influence of Fusarium spp. isolate and inoculum density on resistance screening tests in onion. Tropical Plant Pathology 39:19-27

Ghanbarzadeh B, Mohammadi Goltapeh E, Safaie N (2014) Identification of Fusarium species causing basal rot of onion in East Azerbaijan province, Iran and evaluation of their virulence on onion bulbs and seedlings. Archives of Phytopathology and Plant Protection 47:1050-1062

Ghanbarzadeh B, Safaie N, Mohammadi Goltapeh E, Rezaee Danesh Y, Khelghatibana F (2016) Biological control of Fusarium basal rot of onion using Trichoderma harzianum and Glomus mosseae. Journal of Crop Protection 5:359-368

Gunaratna LNR, Deshappriya N, Jayaratne DL, Rajapaksha RGSAS (2019) Damping-off disease of big onion (Allium cepa L.) in Sri Lanka and evaluation of Trichoderma asperellum and Trichoderma virens for its control. Tropical Plant Research 6:275292
Gupta RC, Gupta RP (2013) Effect of integrated disease management packages on diseases incidence and bulb yield of onion (Allium cepa L.). SAARC Journal of Agriculture 11:49-59

Gutierrez JA, Cramer CS (2005) Screening short-day onion cultivars for resistance to Fusarium basal rot. HortScience 40:157-160

Gutierrez JA, Molina-Bravo R, Cramer CS (2006) Screening wintersown, intermediate-day onion cultivars for resistance to Fusarium basal rot. HortTechnology 16:177-181

Haapalainen M, Latvala S, Kuivainen E, Qiu Y, Segerstedt M, Hannukkala AO (2016) Fusarium oxysporum, F. proliferatum and $F$. redolens associated with basal rot of onion in Finland. Plant Pathology 65:1310-1320

Hanks GR (1996) Control of Fusarium oxysporum f.sp. narcissi, the cause of narcissus basal rot, with thiabendazole and other fungicides. Crop Protection 15:549-558

Havey MJ (1993) 4 - Onion: Allium cepa L. In: Kalloo G, Bergh BO (eds) Genetic improvement of vegetable crops. Pergamon, Amsterdam, pp 35-49

Hoitink HAJ, Boehm MJ (1999) Biocontrol within the context of soil microbial communities: a substrate-dependent phenomenon. Annual Review of Phytopathology 37:427-446

Ilhe BM, Musmade NA, Kawade SB (2013) Management of basal bulb rot of onion (Allium cepa L.). International Journal of Plant Protection 6:349-352

Javaid A, Rauf S (2015) Management of basal rot disease of onion with dry leaf biomass of Chenopodium album as soil amendment. International Journal of Agriculture and Biology 17:142-148

Kalman B, Abraham D, Graph S, Perl-Treves R, Meller Harel Y, Degani O (2020) Isolation and identification of Fusarium spp., the causal agents of onion (Allium cepa) basal rot in Northeastern Israel. Biology (Basel) 9

Kamenetsky R, Rabinowitch HD (2017) Physiology of domesticated Alliums: Onions, garlic, leek, and minor crops. In: Thomas B, Murray BG, Murphy DJ (eds) Encyclopedia of Applied Plant Sciences, 2nd edn. Elsevier Academic Press, Amsterdam, pp 255261

Katis NI, Maliogka VI, Dovas CI (2012) Chapter 5 - Viruses of the genus Allium in the Mediterranean region. In: Loebenstein G, Lecoq H (eds) Advances in Virus Research, vol 84. Elsevier Academic Press, Amsterdam, pp 163-208

Kifle MH, Yobo KS, Laing MD (2017) Biocontrol of Aspergillus flavus in groundnut using Trichoderma harzianum strain kd. Journal of Plant Diseases and Protection 124:51-56

Kintega KR, Zida PE, Soalla R, Tarpaga VW, Sankara P, Sereme P (2020) Determination of Fusarium species associated with onion plants (Allium cepa) in field in Burkina Faso causing damping-off and bulb rots. American Journal of Plant Sciences 11:64-79

Klokocar-Smit ZD, Levic JT, Masirevic SN, Gvozdanovic-Varga JM, Vasic MA, Aleksic SR (2008) Fusarium rot of onion and possible use of bioproduct. Proc. Nat. Sci Matica Srpska Novi Sad 114:135148

Koike ST, Gordon TR, Aegerter BJ (2003) Root and basal rot of leek caused by Fusarium culmorum in California. Plant Disease 87:601601

Köycü ND, Özer N (1997) Determination of seedborne fungi in onion and their transmission to onion sets. Phytoparasitica 25:25-31

Lacy ML, Roberts DL (1982) Yields of onion cultivars in midwestern organic soils infested with Fusarium oxysporum f.sp. cepae and Pyrenochaeta terrestris. Plant Disease 66:1003-1006

Le D, Ameye M, De Boevre M, De Saeger S, Audenaert K, Haesaert G (2020) Population, virulence and mycotoxin profile of Fusarium spp. associated with basal rot of Allium spp. in Vietnam. Plant Disease. First look at https://doi.org/10.1094/PDIS-08-20-1850RE. Accessed 21 Jan 2021

Lee JH, Lee SJ, Park S, Jeong SW, Kim CY, Jin JS, Jeong ED, Kwak YS, Kim ST, Bae DW, Kim GS, Shin SC (2012) Determination of 
flavonoid level variation in onion (Allium cepa L.) infected by Fusarium oxysporum using liquid chromatography-tandem mass spectrometry. Food Chemistry 133:1653-1657

Leoni C, de Vries M, ter Braak CJF, van Bruggen AHC, Rossing WAH (2013) Fusarium oxysporum f.sp. cepae dynamics: in-plant multiplication and crop sequence simulations. European Journal of Plant Pathology 137:545-561

Lopez JA, Cramer CS (2004). Screening short-day onion varieties for resistance to Fusarium basal rot. Pages 169-173 in: International Society for Horticultural Science (ISHS), Leuven, Belgium. Available at: https://doi.org/10.17660/ActaHortic.2004.637.19. Accessed 10 Oct 2020

Lugosch K, Peters RD, Barasubiye T, Drake K (2011) Survey of Fusarium species infecting potato and their resistance to fungicides used in Canada. In: Mendez-Vilas A (ed.) Science and technology against microbial pathogens, World Scientific, Spain. pp. 352-356. Available at: https://doi.org/10.1142/9789814354868_0069. Accessed 15 Jan 2021

Malathi S (2015) Biological control of onion basal rot caused by Fusarium oxysporum f. sp. cepae. Asian Journal of Bio Science 10:21-26

Manimaran P, Madhan Mohan K, Sekarl R (2011) Antagonistic activity of Bacillus species against basal rot disease of onion. Journal of Mycology and Plant Pathology 41:241-245

Marrelli M, Amodeo V, Statti G, Conforti F (2018) Biological properties and bioactive components of Allium cepa L.: focus on potential benefits in the treatment of obesity and related comorbidities. Molecules (Basel, Switzerland) 24:119

Maude RB (1998) Onion diseases. In: Jones DG (ed) The epidemiology of plant diseases. Springer, Dordrecht, pp 404-422

Mishra RK, Jaiswal RK, Kumar D, Saabale PR, Singh A (2014) Management of major diseases and insect pests of onion and garlic: a comprehensive review. Journal of Plant Breeding and Crop Science 6:160-170

Molinero-Ruiz L, Rubio-Pérez E, González-Domínguez E, BasalloteUreba MJ (2011) Alternative hosts for Fusarium spp. causing crown and root rot of asparagus in Spain. Journal of Phytopathology 159: 114-116

Moutassem D, Belabid L, Bellik Y, Ziouche S, Baali F (2019) Efficacy of essential oils of various aromatic plants in the biocontrol of Fusarium wilt and inducing systemic resistance in chickpea seedlings. Plant Protection Science 55:202-217

Muthukumar A, Eswaran A, Sanjeevkumas K (2011) Exploitation of Trichoderma species on the growth of Pythium aphanidermatum in Chilli. Brazilian Journal of Microbiology: Publication of the Brazilian Society for Microbiology 42:1598-1607

Naik DM, Burden OJ (1981) Chemical control of basal rot of onion in Zambia. Tropical Pest Management 27:455-460

Nico AI, González Sánchez M (2012) Response of different intermediateday onion hybrids to natural infestation by Phoma terrestris and Fusarium oxysporum f. sp. cepae in Ciudad Real, Spain with assessment of different soil disinfestation methods. European Journal of Plant Pathology 134:783-793

Özer N, Köycü ND (1998) Evaluation of seed treatments for controlling Aspergillus niger and Fusarium oxysporum on onion seed. Phytopathologia Mediterranea 37:8

Özer N, Ömeroğlu M (1995) Chemical control and determination of fungal causal agents of wilt disease of onion in Terikdağ province. Journal of Turkish Phytopathology 24:47-55

Ozer N, Kycti ND, Mirik M, Soran H, Boyraz D (2002) Effect of some organic amendments on onion bulb rot. Phytoparasitica 30:429-433

Ozer N, Koycu ND, Chilosi G, Magro P (2004) Resistance to Fusarium basal rot of onion in greenhouse and field and associated expression of antifungal compounds. Phytoparasitica 32:388-394

Palmero D, de Cara M, Nosir W, Gálvez L, Cruz A, Woodward S, González-Jaén MT, Tello JC (2012) Fusarium proliferatum isolated from garlic in Spain: identification, toxigenic potential and pathogenicity on related Allium species. Phytopathologia Mediterranea 51: 207-218

Petkar A, Langston DB, Buck JW, Stevenson KL, Ji P (2017) Sensitivity of Fusarium oxysporum f. sp. niveum to prothioconazole and thiophanate-methyl and gene mutation conferring resistance to thiophanate-methyl. Plant Disease 101:366-371

Quesada-Ocampo LM, Butler S, Withers S, Ivors K (2014) First report of Fusarium rot of garlic bulbs caused by Fusarium proliferatum in North Carolina. Plant Disease 98:1009-1009

Rajendran K, Ranganathan K (1996) Biological control of onion basal rot (Fusarium oxysporum f. sp. cepae) by combined application of fungal and bacterial antagonists. Journal of Biological Control 10:97102

Ravi NS, Nagalakshmi MD, Bagyanarayana G (2014) First report of Fusarium proliferatum causing rot of onion bulbs (Allium cepa L.) in India. Science, Technology and Art Research Journal 3:01-03

Retig N, Kust AF, Gabelman WH (1970) Greenhouse and field tests for determining the resistance of onion lines to Fusarium basal rot. Journal of the American Society of Horticultural Science 95:422425

Salvalaggio AE, Ridao AC (2012) First report of Fusarium proliferatum causing rot on garlic and onion in Argentina. Plant Disease 97:556556

Sankar NR, Babu GP (2011) First report of Fusarium proliferatum causing rot of garlic bulbs (Allium sativum) in India. Plant Disease 96: 290-290

Saravanakumari K, Thiruvudainambi S, Ebenezar EG, Senthil N (2019) Efficacy of some fungicides and oil cake extracts against basal rot of onion caused by Fusarium oxysporum. International Journal of Farm Sciences 9:93-96

Satour MM, El-Sherif EM, El-Ghareeb L, El-Hadad SA, El-Wakil HR (1991) Achievements of soil solarization in Egypt. FAO Plant Production and Protection Paper 109:200-212

Saxena A, Cramer CS (2009) Screening of onion seedlings for resistance against new Mexico isolates of Fusarium oxysporum f. sp. cepae. Journal of Plant Pathology 91:199-202

Seefelder W, Gossmann M, Humpf H (2002) Analysis of fumonisin B1 in Fusarium proliferatum - infected asparagus spears and garlic bulbs from Germany by liquid chromatography-electrospray ionization mass spectrometry. Journal of Agricultural and Food Chemistry 50:2778-2781

Shafique S, Shafique S, Bajwa R (2004) Antifungal activity of allelopathic plant extracts V: inhibition in biomass production of Fusarium solani - by aqueous extracts of allelopathic grasses (Cenchrus pennisetiformis, Imperata cylindrica and Dichanthium annulatum). Mycopath 2:83-86

Sharifi Tehrani A, Ramezani M (2003) Biological control of Fusarium oxysporum, the causal agent of onion wilt by antagonistic bacteria. Communications in Agricultural and Applied Biological Science 68:543-547

Sharifi-Rad J, Mnayer D, Tabanelli G, Stojanović-Radić ZZ, Sharifi-Rad M, Yousaf Z, Vallone L, Setzer WN, Iriti M (2016) Plants of the genus Allium as antibacterial agents: from tradition to pharmacy. Cellular and Molecular Biology 62:57-68

Sid Ahmed A, Pérez-Sánchez C, Egea C, Candela ME (1999) Evaluation of Trichoderma harzianum for controlling root rot caused by Phytophthora capsici in pepper plants. Plant Pathology 48:58-65

Sintayehu A, Sakhuja PK, Fininsa C, Ahmed S (2011) Management of Fusarium basal rot (Fusarium oxysporum f. sp. cepae) on shallot through fungicidal bulb treatment. Crop Protection 30:560-565

Sintayehu A, Ahmed S, Fininsa C, Sakhuja PK (2014) Evaluation of green manure amendments for the management of Fusarium basal rot (Fusarium oxysporum f.sp. cepae) on shallot. International Journal of Agronomy 2014:1-6 
Stachewicz H, Burth U, Rathke S (1992). Fungicide resistance of Fusarium spp. on potato in the New Bundeslaender, AGRIS. Available at: https://agris.fao.org/agris-search/search.do?recordID= DE92U0488. Accessed 3 April 2020

Stadnik MJ, Dhingra OD (1997) Root infection by Fusarium oxysporum f. sp. cepae at different growth stages and its relation to the development of onion basal rot. Phytopathologia Mediterranea 36:8-11

Stankovic S, Levic J, Petrovic T, Logrieco A, Moretti A (2007) Pathogenicity and mycotoxin production by Fusarium proliferatum isolated from onion and garlic in Serbia. European Journal of Plant Pathology 118:165-172

Sumner DR, Gitaitis RD, Gay JD, Smittle DA, Maw BW, Tollner EW, Hung YC (1997) Control of soilborne pathogenic fungi in fields of sweet onion. Plant Disease 81:885-891

Swamy KRM, Veere Gowda R (2006) 22 - Leek and shallot. In: Peter KV (ed) Handbook of herbs and spices. Woodhead Publishing, Cambridge, pp 365-389

Taylor A, Vagany V, Barbara DJ, Thomas B, Pink DAC, Jones JE, Clarkson JP (2013) Identification of differential resistance to six Fusarium oxysporum f. sp. cepae isolates in commercial onion cultivars through the development of a rapid seedling assay. Plant Pathology 62:103-111

Taylor A, Teakle GR, Walley PG, Finch-Savage WE, Jackson AC, Jones JE, Hand P, Thomas B, Havey MJ, Pink DAC, Clarkson JP (2019) Assembly and characterisation of a unique onion diversity set identifies resistance to Fusarium basal rot and improved seedling vigour. Theoretical and Applied Genetics 132:3245-3264

Tirado-Ramírez MA, López-Orona CA, Díaz-Valdés T, Velarde-Félix S, Martínez-Campos AR, Romero-Gómez SJ, Retes-Manjarrez JE (2018a) First report of basal rot of onion caused by Fusarium brachygibbosum in Sinaloa, Mexico. Plant Disease 103:582-582

Tirado-Ramírez MA, López-Orona CA, Velázquez-Alcaraz TJ, DíazValdés T, Velarde-Félix S, Martínez-Campos AR, RetesManjarrez JE (2018b) First report of onion basal rot caused by Fusarium falciforme in Mexico. Plant Disease 102:2646

Tonti S, Mandrioli M, Nipoti P, Pisi A, Gallina Toschi T, Prodi A (2017) Detection of fumonisins in fresh and dehydrated commercial garlic. Journal of Agricultural and Food Chemistry 65:7000-7005
Turkkan M, Erper I (2014) Evaluation of antifungal activity of sodium salts against onion basal rot caused by Fusarium oxysporum f.sp. cepae. Plant Protection Sciences 50:19-25

Wibowo A, Kaeni E, Toekidjo T, Subandiyah S, Sulistyaningsih E, Harper S (2016) Responses of four shallot (Allium cepa L. aggregatum group) cultivars to moler disease (Fusarium spp.) after bulb treatment. ISHS Acta Horticulturae 1143. Available at: https:// espace.library.uq.edu.au/view/UQ:418011. Accessed 10 April 2020

Wright P, Falloon R, Hedderley D (2015) Different vegetable crop rotations affect soil microbial communities and soilborne diseases of potato and onion: literature review and a long-term field evaluation. New Zealand Journal of Crop and Horticultural Science 43:85-100

Xu S, Wang J, Wang H, Bao Y, Li Y, Govindaraju M, Yao W, Chen B, Zhang M (2019) Molecular characterization of carbendazim resistance of Fusarium species complex that causes sugarcane pokkah boeng disease. BMC Genomics 20:115

Yadav SL, Ahir RR, Rathore BS, Yadav SM (2014) Efficacy of different fungicides and organic amendments against basal rot of onion caused by Fusarium oxysporum in vitro. Plant Pathology Journal 13:56-58

Yogev A, Raviv M, Hadar Y, Cohen R, Wolf S, Gil L, Katan J (2010) Induced resistance as a putative component of compost suppressiveness. Biological Control 54:46-51

Zhang W, Dick WA, Hoitink HAJ (1996) Compost-induced systemic acquired resistance in cucumber to Pythium root rot and anthracnose. Phytopathology 86:5

Zhang YP, Ma LL, Yang XM, Wang JH, Qu SP, Xu F, Wang LH (2016) First report of bulb rot of Allium giganteum caused by Fusarium avenaceum in China. Plant Disease 100:2335

Simey EI (1990) Garlic rot caused by Fusarium proliferatum (Matsushima) Nirenberg var. minus Nirenber in Hungary. Novenyvedehem 26:397-399

Publisher's note Springer Nature remains neutral with regard to jurisdictional claims in published maps and institutional affiliations. 